and heard an excellent exposition of the moral and legal problems involved. It is the public and Parliament, not doctors, that will have to make the moral and legal decisions, and the more they know about the subject the better.I am, etc.,

Oxford.

J. M. K. Spalding.

Sir.-Your leading article on "Disease Education by the B.B.C." (Journol. February 15. p. 338) and the statement by the B.M.A. spokesman following the "Ray of Hope" programme prompt us to correct a misleading remark made by the physician in the department of medicine of a London teaching hospital following the otherwise admirable transmission from the Christie Hospital and Holt Radium Institule, of which Manchester and its regional hospital board are justly proud. It is unfortunately untrue that facilities and apparatus for cancer treatment of the type shown are available in each region of the country. The Birmingham Regional Hospital Board serves a population larger than that of any other hospital board except the South-west Metropolitan, and yet it is still without the supervoltage $r$-ray and large telecurie units installed in all the other hospital regions in England and Wales. Although it is to be hoped that the Ministry will see fit to approve the United Birmingham Hospitals' plan to build and properly equip a radiotherapy centre for the Birmingham area, it was not proper to mislead the inhabitants of this region into believing that the modern equipment as shown on their television screens is available in the West Midlands. -We are, etc.,

W. H. BOND.

Edgbaston, Birmingham.

P. B. KUNKLER.

SIR,-I wrote to the director-general of B.B.C. television recently about the effects of his broadcast on homosexuality on a patient. In the course of his reply be stated, "However careful we are over such broadcasts, there must, regrettably, be some-we believe very few-who may be harmed by what they see or hear." Is not this admission sufficient to condemn these broadcasts out of hand ?

We, as doctors, have two duties to perform. The one, the quiet and careful explanation to the worried patient of the garbled version he may have picked up from the screen and the investigation of his symptoms. The other, the support of your campaign for an end to these sort of broadcasts by ensuring that any cases affected by them receive at least a numerical publicity.-I am, etc.,

Harwich.

B. L. Hoskyns.

\section{Infertile Marriage}

SiR,- Mr. Hubert Campbell is to be congratulated on his excellent paper on infertility (Journal, February 22, p. 429). His last sentence in large print emphasizes the encouragement that sterile couples need. Generally we can achieve very little for them by investigation or by surgery. but with a little effort we can ensure that they leave us happier and more hopeful than when they came. This is the most important point in their management-I am, etc.,

Leeds, 2.

Andrew M. Claye.

\section{Scabies on the Increase ?}

Sir,-Dr. Allan Bigham's letter (Journal, February 8, p. 338) suggesting that scabies may be on the increase interested me considerably. Although I am not to-day actively concerned with human parasitology, I have heard rumours from other sources of a similar increase.

Conditions exist to-day which, in my opinion, make it not unlikely that a serious increase in the incidence of scabies will occur during the next few years. As I showed some time ago, ${ }^{1}$ it is much easier to infect those who have never had scabies than those who have previously suffered from the disease. To-day few children born since 1945 have ever harboured the Sarcoptes, and so they are very susceptible.
It should be remembered that the epidemic which was usually connected with the 1939-45 war had in fact started several years before 1939, and that it was not caused by airraids or uncleanliness. In fact Sarcoptes can survive better in clean than in dirty skin, though the clinical picture (often uncomplicated by secondary infection) may be different, and may not be easily recognized by those who still look upon scabies as a "dirt" disease.-I am, etc.,

Harpenden, Herts.

KenNeth Mellanby.

1 Mellanby, K., Scabies, 1944. Oxford University Press.

\section{Suicide as a Crime}

SIR,-As chairman of the joint committee of doctors and magistrates set up by the B.M.A., I should like to draw attention to the leader in The Times of February 26, and a number of letters previously published in that newspaper, strongly urging a change in the law so that suicide, and consequentially attempted suicide, would no longer be legal offences. This supports the recommendation of the medical members in my committee's 1947 report that "there is a strong case for an amendment of the law so that attempted suicide-excluding attempted 'suicide pacts' or incitement of another person to commit suicide-would not be dealt with as a legal offence."

It will be recalled that the Representative Body at the meeting in Brighton in 1956 passed the following resolution without any dissentients (Supplement, July 21, 1956, p. 62):

"That this meeting notes with concern the fact that in recent years a considerable number of people have been imprisoned for attempting sucide. It supports the statement of the Joint Committee of the B.M.A. and Magistrates' Association in their report on attempted suicide and the Law (1947)."

This is therefore the policy of the B.M.A.

Practically every case of attempted suicide is seen by a doctor at some stage after the attempt ; medical practitioners therefore have a wider experience than any other members of the community and are in a better position to understand and deal with the problems that arise in such cases, both in relation to the person who attempts suicide and the interests of the community.

On February $6 \mathrm{Mr}$. Kenneth Robinson asked the Home Secretary in the House of Commons whether he was prepared to initiate legislation to remove suicide and attempted suicide from the category of criminal offences. Mr. Butler replied that he had no evidence that a change in the law would be universally acceptable to public opinion. He based the concept of suicide as a crime on the religious attitude that it was a sin (see Journal, February 15, p. 405). It is very doubtful, however, if this was the basis of the law. Suicide has been a felony in common law since mediaeval times, and the penalty was forfeiture of property to the Crown as well as burial at a cross-roads with a stake through the heart. No penalty for successful suicide has been imposed since the latter part of the last century. However, strangely enough, the first prosecution for attempted suicide occurred in 1854, and this practice has continued right up to the present time, though no one appears to know why this was started.

Professor Glanville Williams, of Cambridge, and Professor Mannheim point out in their letters to The Times (February 11 and 25) that only in India and some States of U.S.A. is attempted suicide regarded as a legal offence. In all other parts of the world, including Scotland, it is dealt with through the medical and social services, and they do not appear to feel the need for any legal sanctions. In this country also it could normally be dealt with by similar means. In the rare case where an attempted suicide refuses to co-operate, the police have power to remove him compulsorily to a general hospital if he is in need of medical care, or, if his mental state is in question, they can arrange (if desired through a Duly Authorized Officer) for him to go to a hospital for observation on a three-day 
Order. There he can be kept for up to 28 days. Thus there is no reason to invoke legal interventions by the courts to protect the individual from himself. If a case should arise in which the public weal might be threatened, the attempted suicide could be dealt with by the "breach of the peace" procedure. This is the practice in Scotland and has proved to be adequate. It is less and less used even there as better medical and social facilities become available.

A great many medical men and women, including Professor E. Stengel, of Sheffield, and Dr. Phyllis Epps, of Holloway Prison, who have both made special studies of cases of attempted suicide, feel that the present law and practice are definitely detrimental to the well-being and hope of recovery of the attempted suicide and interfere with medical and social treatment and rehabilitation. As The Times leader expressed it, "The effect of a prison sentence on an already desperately distressed individual and on his family is often grievously punitive in ways not intended, as well as prejudicial to recovery of equanimity." This applies not only to imprisonment but also to the presence of a policeman or policewoman by the bed in hospital, by a charge before the court, by conviction of a criminal offence, or by remand to prison as a convicted criminal for the medical report of the prison doctor.

The Times leader comes down firmly on the side of abrogating the law on suicide and presents an admirable summary of the reasons for so doing. It also states :

"The array of legal and medical experts ... against the present law is impressive, and there seems to be no weighty body of expert opinion on the other side. No one has argued convincingly against the views of Professor Glanville Williams and Dr. Mannheim in recent letters to The Times. It is not easy to do so, for the Scots have no such law nor (with trifling exceptions) has the rest of the civilized world."

The Joint Committee of the B.M.A. and the Magistrates' Association are reconsidering the question of the law and practice in relation to suicide and attempted suicide, and hope to publish a further report shortly. It is encouraging that the report of over 10 years ago, which was the first attempt to draw public attention to this sad problem of human suffering, is now beginning to show results.-I am, etc.,

Bournemouth, Hants.

DORIS ODLUM

\section{Scarlet Red Dressing}

SIR,-Scarlet red is a medicament that has been used for several decades for the promotion of epithelial growth in wounds. Unfortunately it suffers from one or two disadvantages-it can be irritant if used in concentrations exceeding $5 \%$, and it is usually presented as a suspension in a paraffin base, which is messy in use and inclined to stain everything with which it comes into contact. As we were interested in the possibilities of this material, we have attempted to improve upon its formulation.

Tins similar to those used for paraffin gauze dressing B.P.C. were obtained, and a close-weave rayon cloth was cut into standard sizes and placed therein. The dressing was impregnated with a medicated base consisting of scarlet red B.P.C. (0.2 g.), propylene glycol (33.2 g.), polyethylene glycol $4,000$ (33.3 g.), and polyethylene glycol 555M ( $33.3 \mathrm{~g}$.$) . The$ last-named item is a blend of polyethylene glycols 1500 and 300 (Messrs. Oxirane Ltd.). The tins are heated at $135^{\circ} \mathrm{C}$. for 30 minutes. Alternatively they may be autoclaved at $125^{\circ} \mathrm{C}$. for 30 minutes if care is exercised. A partial vacuum is applied after sterilizing and the tins allowed to dry out in the autoclave before removal.

The scarlet red is in solution in the base, which is watersoluble; thus an intimate proximation of drug and wound surface can occur, an ideal state which allows the percentage of drug to be as low as 0.2. Another advantage found in practice is the relative lack of staining associated with the preparation. The base chosen, being water-soluble, is easily removed and does not impede the draining of the wound. The proportions of the three ingredients may be adjusted to produce a base of the desired consistency. The rayon cloth peels cleanly from the wound, leaving the surface dry and free of " sogginess" in contradistinction to the standard tulle gras dressing. Another advantage of a close-weave material is that granulations cannot grow through the mesh making removal difficult.

The new dressing has been used for some months for skin-graft donor areas and the rate of healing has been highly satisfactory. The donor areas have remained dry and free from infection, and the maceration sometimes associated with soft paraffin dressings has been entirely avoided. Further work is being performed upon the use of this dressing. -We are, etc.,

$$
\begin{array}{ll} 
& \text { P. H. JAYES. } \\
\text { East Grinstead, Sussex. } & \text { F. H. SUMMERS. }
\end{array}
$$

\section{Problems of Puberty}

SIR,-There is nothing straightforward about the management of masturbatory guilt in adolescents. Each puzzled young man needs an intent listener prepared to force him to question his most cherished beliefs, after which he will come to a control of himself or he will indulge a clamant need according to what is best for him. That at least is my aim with these people. Dr. R. N. B. Byatt (Journal, February 15, p. 397) points to a different state of affairs, and one feels with him that in the face of mass pornography and guiltless auto-eroticism the medical profession dare not pursue a course of laisser faire. This attitude is not met with inside the doctor's consulting-room. However, I would like to comment on the term laisser faire. Where this attitude does exist one cannot help feeling that it may be associated in the mind of the doctor with his own masturbatory anxieties, so that he sees himself as a bad counsellor of youth and, perhaps wisely, refrains from a task for which he is essentially badly equipped.

To resolve one's own anxieties by taking up a totally condemnatory attitude is useless or positively harmful. As physician in charge of an undergraduate health service I would like to record the story of a disturbed student who told me during a second or third interview that when he was about fifteen a school medical officer, commenting on his small genitalia, had told him to masturbate, saying, "You know it does you more good than harm, don't you ?" For several years after this he used to masturbate once or twice a week, always with loathing. Then be became interested in joining a Church ministry, and he confided his masturbatory condition to a clergyman, who told him with kindliness to give up a practice which is " against the rules of the Church." With this advice he stopped masturbating; he lost much of his guilt feeling, but he was in a pathological state bordering on hypomania. I found him inaccessible. I never managed to get him to see a possibility of 'his having any right of say in the matter.

Fortunately most young people are not so vulnerable to advice, but we dare not mete out advice based on our own preconceptions, unrelated to the real situation. To see this properly involves much time and energy, so that on the whole we are in no position to give any advice in these matters. Laisser faire is not such a bad policy.-I am, etc.,

Bristol. 8.

Agnes Wilkinson.

\section{Informal Admission of Mental Defectives}

SIR,-In his letter in your issue of February 22 (p. 458) Dr. Donald McI. Johnson accuses me of a lack of understanding of public sentiment regarding the compulsory detention of mental defectives. I would ask that he and anyone who shares this view refer to my letter in your issue of May 11, 1957 (p. 1120). In that letter I think Dr. Johnson will find that I discussed the very points raised in his more recent letter, and that we are in fact in agreement on most of them. He will realize, too, that I share his disapproval of the detention of an honours B.A. in a mental defective colony.

I cannot agree, however, with Dr. Johnson "that the 'social incapacity' of the so-called feeble-minded patient 